\title{
Retraction \\ Retracted: Innovative Therapies against Human Glioblastoma Multiforme
}

\author{
International Scholarly Research Notices
}

Received 2 July 2019; Accepted 2 July 2019; Published 22 August 2019

Copyright (C) 2019 International Scholarly Research Notices. This is an open access article distributed under the Creative Commons Attribution License, which permits unrestricted use, distribution, and reproduction in any medium, provided the original work is properly cited.

International Scholarly Research Notices has retracted the article titled "Innovative Therapies against Human Glioblastoma Multiforme" [1]. The article was found to contain a substantial amount of material from previously published articles, including the following sources:

(i) Lefranc F., Facchini V., and Kiss R. (2007): "Proautophagic Drugs: A novel Means to Combat ApoptosisResistant Cancers, with a Special Emphasis on Glioblastomas," Oncologist 12, 1395-1403, https://doi.org/10.1634\% 2ftheoncologist.12-12-1395 [2] (cited as [129]).

(ii) Furnari FB, Fenton T, Bachoo RM, Mukasa A, Stommel JM, and Stegh A, et al.: "Malignant Astrocytic Glioma: Genetics, Biology, and Paths to Treatment," Genes Dev 2007; 21:2683-710, https://doi.org/10.1101/gad.1596707, Genes \& Dev. 2007. 21: 2683-2710 [3] (not cited).

(iii) Elisabetta Benedetti: "PPARs in Human Neuroepithelial Tumors: PPAR Ligands as Anticancer Therapies for the Most Common Human Neuroepithelial Tumors," PPAR Research, 2010, https://doi.org/10.1155\%2f2010\%2f427401 [4] (cited as [127]).

(iv) Ryuya Yamanaka: "Cell- and Peptide-Based Immunotherapeutic Approaches for Glioma," Trends in Molecular Medicine, 2008, https://doi.org/10.1016\%2fj.molmed.2008 .03 .003 [5] (cited as [2]).

(v) Azizul Haque: "Emerging Role of Combination of All-Trans Retinoic Acid and Interferon-gamma as Chemoimmunotherapy in the Management of Human Glioblastoma," Neurochemical Research, 11/01/2007, https://doi.org/ 10.1007\%2fs11064-007-9420-z [6] (cited as [121]).

\section{References}

[1] A. Cimini and R. Ippoliti, "Innovative therapies against human glioblastoma multiforme," ISRN Oncology, vol. 2011, Article ID 787490, 12 pages, 2011.
[2] F. Lefranc, V. Facchini, and R. Kiss, "Proautophagic drugs: A novel means to combat apoptosis-resistant cancers, with a special emphasis on glioblastomas," The Oncologist, vol. 12, no. 12, pp. 1395-1403, 2007.

[3] F. B. Furnari, T. Fenton, R. M. Bachoo, A. Mukasa, J. M. Stommel, A. Stegh et al., "Malignant astrocytic glioma: genetics, biology, and paths to treatment," Genes \& Development, vol. 21, pp. 2683-2710, 2007.

[4] E. Benedetti, R. Galzio, B. D’Angelo, M. P. Cer, and A. Cimini, "PPARs in human neuroepithelial tumors: PPAR ligands as anticancer therapies for the most common human neuroepithelial tumors," PPAR Research, vol. 2010, Article ID 427401, 9 pages, 2010.

[5] R. Yamanaka, "Cell- and peptide-based immunotherapeutic approaches for glioma," Trends in Molecular Medicine, vol. 14, no. 5, pp. 228-235, 2008.

[6] A. Haque, N. L. Banik, and S. K. Ray, "Emerging role of combination of all-trans retinoic acid and interferon-gamma as chemoimmunotherapy in the management of human glioblastoma," Neurochemical Research, vol. 32, no. 12, pp. 2203-2209, 2007. 